\title{
Studi Ekosistem Terumbu Karang di Taman Nasional Kepulauan Seribu
}

\author{
Study of Coral Reef Ecosystem in Taman Nasional Kepulauan Seribu
}

\author{
Linda Noviana $^{\mathrm{a}}$, Hadi Susilo Arifin ${ }^{\mathrm{b}}$, Luky Adrianto ${ }^{\mathrm{c}}$, Kholil $^{\mathrm{d}}$ \\ ${ }^{a}$ Program Studi Pengelolaan Sumberdaya Alam dan Lingkungan, Institut Pertanian Bogor, Kampus IPB Darmaga Bogor, 16680, \\ Indonesia \\ ${ }^{\mathrm{b}}$ Departemen Arsitertur dan Lansekap, Institut Pertanian Bogor, Kampus IPB Darmaga Bogor, 16680, Indonesia \\ ${ }^{\mathrm{c}}$ Departemen Perikanan dan Kelautan, Institut Pertanian Bogor, Kampus IPB Darmaga Bogor, 16680, Indonesia \\ ${ }^{\mathrm{d}}$ Universitas Sahid Jakarta, Indonesia
}

\section{Article Info:}

Received: 05 - 07 - 2018

Accepted: 14 - $09-2018$

Keywords:

coral reef, kepulauan seribu, marine ecotourism

Corresponding Author:

Linda Noviana

Program Studi Pengelolaan

Sumber daya Alam dan

Lingkungan, Institut Pertanian

Bogor

Email:

lindanoviana@yahoo.com

\begin{abstract}
Taman Nasional Laut Kepulauan Seribu (TNLKpS) has a unique natural resource is the natural beauty of the sea and coral ecosystems are unique. But along with the rapid population growth of Jakarta as the capital city and the increasing number of tourists also affect the condition of coral reefs in TNLKpS. This study aimed to analyze and assess the ecological condition of coral reef ecosystems in the utilization zone travel TNLKpS by coral cover life and death, diversity as well as the factors causing the damage of the survey line intercept transect (LIT), literature review, interviews and analysis of the condition of coral reefs by Decree LH No. 4 of 2001 on Baku Criteria Damage Coral Karan. Condition of the reef by live coral cover otherwise damaged to moderate, based on the otherwise dead coral cover damaged high to moderate damage, then the number and type of reef fish more on the depth of 10 meters in comparison with 3 meters. The condition of coral reef ecosystems is common in 3 islands (Pulau Putri, Pulau Macan and Pulau Angin Angin Genteng) in TNKS is still quite good, but in some snorkeling spots it looks bad (3 stations) and medium (2 stations) when compared to spots diving (only 1 bad station).
\end{abstract}

How to cite (CSE Style $8^{\text {th }}$ Edition):

Noviana L, Arifin HS, Adrianto L, Kholil. 2019. Studi ekosistem terumbu karang di Taman Nasional Kepulauan Seribu. JPSL 9(2): 352-365. http://dx.doi.org/10.29244/jpsl.9.2.352-365.

\section{PENDAHULUAN}

Terumbu karang merupakan salah satu kekayaan alam yang bernilai tinggi dan juga menjadi salah satu potensi sumber daya laut yang sangat penting di Indonesia. Wilayah Kepulauan Seribu merupakan salah satu wilayah yang memiliki potensi ekosistem terumbu karang yang tinggi dengan keragaman biota karang yang besar seperti ikan karang. Menurut Souter dan Linden (2000), terumbu karang adalah salah satu ekosistem paling produktif dan beragam di bumi serta memberikan banyak jasa ekosistem. Salah satu fungsi terumbu karang adalah sebagai habitat berbagai jenis ikan dan biota laut lain yang memungkinkan terwujudnya rantai makanan di lokasi tersebut. Selain berfungsi sebagai habitat bagi biota laut, terumbu karang juga memiliki keindahan yang menjadi daya tarik bagi wisatawan bahari.

Kepulauan Seribu mempunyai potensi besar untuk pengembangan wisata bahari, salah satu objek daya tarik wisatawan adalah terumbu karang. Hal ini dapat dilihat dari semakin meningkatnya jumlah kunjungan wisatawan sejak tahun 2003. Bahkan pada tahun 2013 jumah wisatawan mencapai 1500504 orang dan 
meningkat pada tahun 2014 menjadi 2120058 orang, meskipun terdapat penurunan pada tahun 2015 menjadi 1251886 orang (Suku Dinas Pariwisata dan Kebudayaan 2016).

Potensi kawasan dan pemanfaatan sumber daya alam laut di wilayah Kepulauan Seribu sangat tinggi. Oleh karena itu, Wilayah Kepulauan Seribu ditetapkan menjadi Taman Nasional Laut dengan Keputusan Menteri Kehutanan Nomor 162/Kpts-II/1995 dan No. 6310/Kpts-II/2002 yang dikelola oleh Balai Taman Nasional Laut Kepulauan Seribu, Departemen Kehutanan.

Semenjak dikukuhkan sebagai Taman Nasional, banyak wisatwan yang datang berkunjung ke tempat tersebut dan akhirnya turut mempengaruhi kondisi terumbu karang di TNKS. Selain itu, pencemaran air oleh limbah rumah tangga dan industri, penimbunan sampah, penambangan pasir dan karang batu, penebangan mangrove turut menyumbang terjadinya kerusakan terumbu karang. Berdasarkan data dari Terangi (2016), persentase tutupan karang hidup pada tahun 2011 sebesar 39.35\%, tahun 2013 sebesar $35.51 \%$ dan pada tahun 2015 sebesar 32.23\%. Dari data tersebut terlihat kondisi karang hidup mengalami penurunan dari tahun ke tahun. Hal ini dapat disebabkan adanya aktivitas wisatawan ataupun aktivitas lainnya. Jika hal ini dibiarkan terus menerus, maka degradasi terumbu karang semakin tidak terkendali. Untuk itu perlu dikaji bagaimana kondisi saat ini, apa penyebabnya dan bagaimana solusinya agar terumbu karang tetap lestari.

Penelitian ini bertujuan untuk menganalisis dan mengkaji kondisi ekologis ekosistem terumbu karang pada zona pemanfaatan wisata TNKS berdasarkan tutupan karang hidup dan mati, serta mengetahui jumlah dan jenis ikan karang yang menjadi indikator terhadap keberadaan terumbu karang pada TNKS.

\section{METODE}

\section{Lokasi dan Waktu Penelitian}

Penelitian dilakukan pada bulan Maret 2016 sampai Februari 2017, dengan lokasi perairan pada zona pemanfaatan wisata TNLKpS, Jakarta Utara, Provinsi DKI Jakarta. Stasiun penelitian ditentukan berdasarkan jumlah wisatawan paling banyak, yaitu pada Pulau Putri, Pulau Macan dan Pulau Kayu Angin Genteng. Pada setiap stasiun dibuat sub stasiun berdasarkan arah mata angin sebanyak 4 titik sampling, sehingga diharapkan dapat mewakili seluruh daerah kajian.

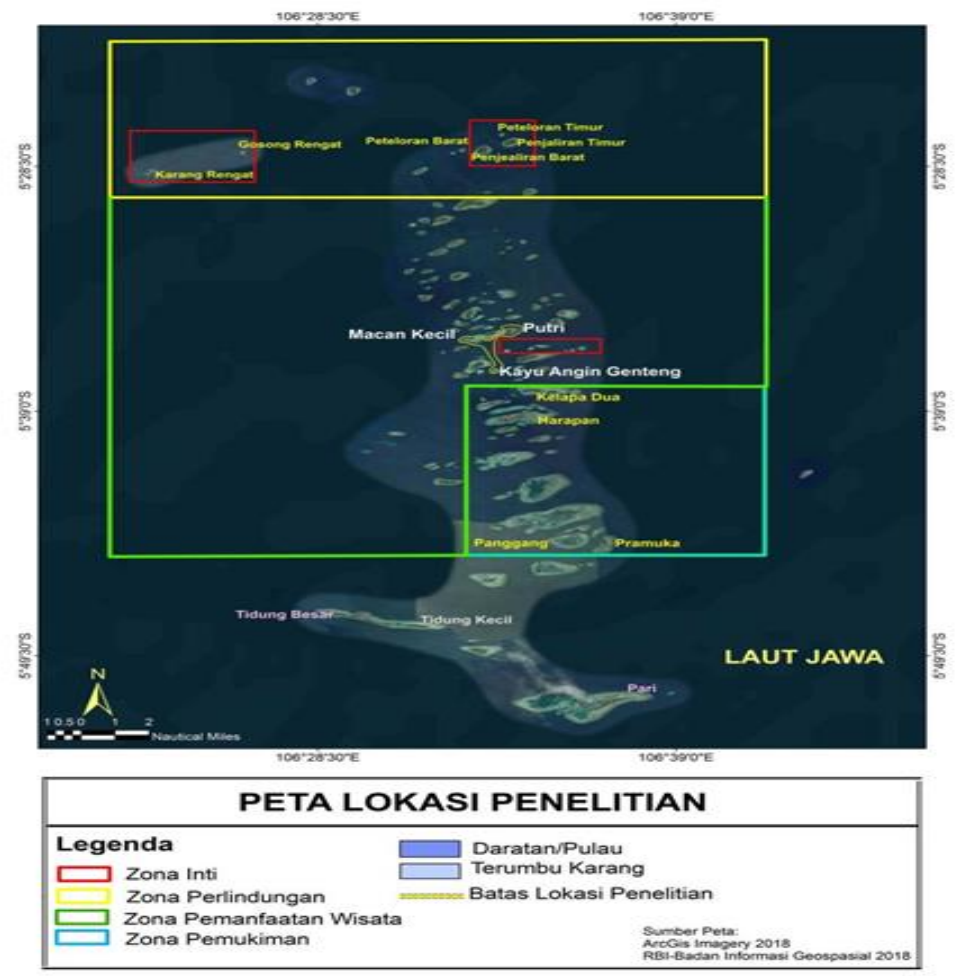

Gambar 1 Peta lokasi penelitian 


\section{Sumber Data}

Data dalam penelitian ini terdiri dari data primer yaitu data parameter lingkungan perairan dan data komunitas karang yang diperoleh melalui pengamatan langsung/observasi serta wawancara kepada pemandu wisata, masyarakat pesisir dan wisatawan untuk melengkapi informasi yang diperlukan dan dianggap penting. Sedangkan data sekunder diperoleh melalui studi literatur dari buku referensi, hasil studi penelitian terdahulu dan dokumen-dokumen yang terkait dengan penelitian untuk menunjang dan melengkapi data yang diperlukan.

Pengukuran parameter fisik kimia perairan sebagai pembatas kehidupan karang dilakukan secara in situ sebelum pengamatan terumbu karang mencakup temperatur, kedalaman, kecepatan arus, $\mathrm{pH}$, DO, dan salinitas. Pengamatan persen tutupan karang dilakukan langsung di lapangan dengan menggunakan metode Line Intercept Transect (LIT), dengan menarik garis transek sepanjang $75 \mathrm{~m}$ (3 kali ulangan $20 \mathrm{~m}$ dan jeda 5 m). Selanjutnya dianalisis berdasarkan Kepmen LH No. 4 tahun 2001 tentang Kriteria Baku Kerusakan terumbu Karang.

\section{Metode Analisis Data}

Analisis data kondisi terumbu karang dan data parameter fisik lingkungan disajikan dan dianalisis secara kuantitatif yang dilakukan dengan menggunakan teknik statistik deskriptif dimana hasil pengolahan data disusun dan diringkas secara ilmiah dalam bentuk tabel atau grafik/diagram dan dibahas secara mendalam dengan mengacu pada berbagai referensi dan literatur pustaka.

\section{Persentase tutupan karang}

Data penutupan karang yang diperoleh dari pengukuran life form karang dihitung dengan rumus (English et al. 1997)

$$
\mathbf{L}=\frac{\mathbf{L} \mathbf{i}}{\mathrm{N}} \times 100 \%
$$

Dimana:

$\mathrm{L}=$ persentase penutupan karang $(\%)$

$\mathrm{Li}=$ panjang total life form jenis kategori ke-i (m)

$\mathrm{N}=$ panjang transek garis $(\mathrm{m})$

Kondisi penutupan terumbu karang diperoleh dari jumlah persentase penutupan karang batu yang didapat dengan kategori sebagai berikut: 76-100\% (baik sekali); $51-75 \%$ (baik); $25-50 \%$ (sedang); 0-25 (buruk). Persentase tutupan adalah persentase luas area yang ditutupi oleh pertumbuhan karang. Persentase karang hidup yang tinggi menandakan bahwa terumbu karang di suatu perairan berada dalam keadaan sehat.

\section{Analisis kelimpahan ikan karang}

Analisis kelimpahan ikan karang yang terdapat pada perairan menggunakan rumus yang dikemukakan oleh Odum (1993), yaitu:

Kelimpahan Ikan $=\mathrm{Xi} / \mathrm{Lind} / \mathrm{m} 2 \ldots . .(2)$

Dimana:

XI = Jumlah individu ikan karang pada stasiun ke-I (ind)

$\mathrm{L} \quad=$ Luas stasiun pengamatan $\left(250 \mathrm{~m}^{2}\right)$.

\section{Analisis Kualitas Air}

Parameter kualitas air yang digunakan dalam dalam penelitian ini adalah $\mathrm{pH}, \mathrm{DO}$, suhu, kecerahan, salinitas, arus dan kecepatan air (Tabel 1). 
Tabel 1 Parameter kualitas perairan

\begin{tabular}{|c|c|c|c|c|}
\hline \multirow[b]{2}{*}{ Parameter } & \multicolumn{3}{|c|}{ Stasiun Penelitian } & \multirow{2}{*}{$\begin{array}{l}\text { Baku Mutu Air Laut Untuk } \\
\text { Biota Laut } \\
\text { (KepMenLH No 51/2004) }\end{array}$} \\
\hline & $\begin{array}{l}\text { Pulau Kayu angin } \\
\text { genteng }\end{array}$ & Pulau Macan & Pulau Putri & \\
\hline $\mathrm{pH}$ & 8.4 & 8.2 & 8.4 & $7-8.5$ \\
\hline Do $(\mathrm{mg} / \mathrm{l})$ & 5.9 & 7.3 & 6.2 & $>5$ \\
\hline Suhu $\left({ }^{0} \mathrm{C}\right)$ & 31 & 29.9 & 31.3 & $28-30$ \\
\hline Kecerahan (meter) & 9.2 & 8.1 & 9.1 & $>5$ \\
\hline Salinitas (ppt/\%o) & 31.5 & 32.1 & 31.3 & $33-34$ \\
\hline \multicolumn{5}{|l|}{ Arus } \\
\hline $\operatorname{Arah}\left({ }^{0}\right)$ & $250^{\circ}$ & $265^{\circ}$ & $305^{\circ}$ & $0.03-0.33$ \\
\hline $\operatorname{Kecepatan}(\mathrm{m} / \mathrm{s})$ & 0.057 & 0.330 & 0.029 & \\
\hline Depth $1(\mathrm{~m})$ & 9.6 & 8.2 & 9.5 & 0 \\
\hline Depth 2 (m) & 8.8 & 8.0 & 8.7 & $0-20$ \\
\hline
\end{tabular}

Sumber: Olahan data primer (2016)

\section{HASIL DAN PEMBAHASAN}

\section{Kondisi Terumbu Karang}

Ekosistem terumbu karang dan segala kehidupan yang terdapat di dalam laut merupakan salah satu sumber daya alam yang bernilai tinggi. Terumbu karang sebagai ekosistem esensial di perairan laut mempunyai peran sangat penting bagi kelangsungan hidup biota laut seperti ikan dan biota-biota lainnya. Pertumbuhan terumbu karang secara optimum memerlukan perairan yang jernih, suhu yang hangat, gerakan gelombang, sirkulasi lancar, serta terhindar dari proses sedimentasi.

Ekosistem terumbu karang merupakan bagian dari ekosistem laut yang penting karena menjadi sumber kehidupan bagi beraneka ragam biota laut. Di dalam ekosistem terumbu karang ini pada umumnya hidup lebih dari 300 jenis karang, yang terdiri dari sekitar 200 jenis ikan dan berbagai jenis molluska, crustacea, sponge, algae, lamun dan biota lainnya (Dahuri 2003). Terumbu karang mempunyai fungsi yang sangat penting sebagai tempat memijah, mencari makan, daerah asuhan bagi biota laut dan sebagai sumber plasma nutfah. Keberadaan terumbu karang dari tahun ke tahun mengalami kemunduran, yaitu terjadi kerusakan yang mengkhawatirkan sehingga menimbulkan penyusutan dalam jumlah kuantitas dan kualitas. Kerusakan ekosistem terumbu karang tidak terlepas dari aktivitas manusia baik di daratan maupun pada ekosistem pesisir dan lautan.

Secara umum terumbu (coral) di gugusan Kepulauan Seribu tumbuh membentuk susunan terumbu karang (coral reef) di sekitar pantai hingga ke arah laut yang lebih dalam dengan luas beberapa feet. Berdasarkan hasil pengamatan dapat diketahui bahwa tipe terumbu karang di sekitar Kepulauan Seribu termasuk Pulau Putri, Macan Kecil dan Kayu Angin Genteng adalah berbentuk patch reef atau biasa disebut pulau datar (reef island). Hal ini dapat diamati dari struktur pertumbuhan secara vertikal dari bawah ke atas permukaan lauatan. Terbentuk dari sisa-sisa pecahan kerang-kerangan (gastropoda dan bivalvia) organisme karang (coral, algae, malusho, foraminifera) dan organisme pesisir dan laut lain dalam kurun waktu yang lama, melalui proses dinamika secara alami, berkembang menjadi semakin luas dan pada akhirnya membentuk daratan baru di sekitarnya (Estradivari 2007; Anggraini 2008)

Sedikitnya 50\% dari 4750 ha terumbu karang yang ada di sekitar Gugusan Kepulauan Seribu kini kondisinya sangat memprihatinkan. Saat ini luas terumbu karang yang masih tersisa dan dapat dimanfaatkan untuk objek wisata dan penelitian ilmiah sekitar 2375 ha (Dinas Kelautan dan Pertanian Kabupaten Kepulauan Seribu 2010). Berdasarkan analisis citra satelit Landsat 8 tahun 2016, diketahui total tutupan terumbu pada Pulau Putri, Macan Kecil dan Kayu Angin Genteng sebesar 64.4 ha atau 1.53\% dari total luas terumbu karang dalam Gugusan Kepulauan Seribu. Tipe terumbu karang patch reef di ketiga pulau dengan 
bentuk pertumbuhan secara vertikal dari bawah ke atas, cenderung membentuk daratan baru dengan subtrat penyusun ialah coral.

Berdasarkan analisis visual terumbu karang pada Pulau Putri dan Kayu Angin Genteng umumnya berada pada reef flate zone di kedalaman 1.5 sampai dengan $5 \mathrm{~m}$, hingga pada kedalaman 6 hingga lebih dari $12 \mathrm{~m}$ pada reef slope zone mengelilingi pulau, sedangkan Pulau Macan Kecil terumbu karang tumbuh mengkuti kontur dasar laut pada reef flate, sebagian tumbuh pada lagoon hingga menuju reef slope. Kondisi ini menciptakan variasi terumbu karang di beberapa lokasi menyesuaikan dengan topografi perairan Pulau Macan Kecil, jika dibanding pada Pulau Putri dan Kayu Angin Genteng. Menurut Goh dan Sasekumar (1980), jenis karang massive lebih mendominasi pada karang dangkal (reef flate), terdapat zona transisi dari beberapa jenis karang Acropora branching tumbuh lebih ke arah darat dan sebagian pada reef slope depan di kedalaman $15 \mathrm{~m}$.

Pengamatan terumbu karang di sekitar perairan Pulau Putri, Macan Kecil dan Kayu Angin Genteng dilakukan masing-masing pada empat stasiun yang mewakili sebaran ekologi tutupan terumbu karang di kawasan tersebut. Penempatan stasiun dilakukan pada perairan yang mewakili kedalaman laut dangkal dan laut yang lebih dalam, juga sering dijadikan spot wisata bahari potensial oleh wisatawan. Berdasarkan hasil pengamatan terumbu karang dan pengukuran parameter yang terkait dalam ekosistem ini, diperoleh hasil sesuai dalam Tabel 2.

Tabel 2 Kondisi tutupan terumbu karang pada 3 pulau (12 stasiun)

\begin{tabular}{lcccc}
\hline \multirow{2}{*}{$\begin{array}{c}\text { Lokasi Terumbu } \\
\text { Karang }\end{array}$} & Persen (\%) Tutupan Karang & Kategori & Persen (\%) Tutupan Karang & Kategori \\
\cline { 2 - 5 } Pulau Putri & & & & \\
ST1 (Timur) & 40.02 & Sedang & 50.32 & Sedang \\
ST2 (Selatan) & 43.93 & Sedang & 50.14 & Sedang \\
ST3 (Barat) & 22.37 & Buruk & 27.55 & Buruk \\
ST4 (Utara) & 18.13 & Buruk & 24.81 & Buruk \\
\hline Pulau Macan Kecil & & & & \\
ST1 (Timur) & 19.72 & Buruk & 50.18 & Sedang \\
ST2 (Selatan) & 45.71 & Sedang & 50.78 & Baik \\
ST3 (Barat) & 50.25 & Sedang & 51.08 & Baik \\
ST4 (Utara) & 34.18 & Buruk & 51.32 & Baik \\
\hline Pulau Kayu Angin Genteng & & & & \\
ST1 (Timur) & 37.33 & Buruk & 55.05 & Baik \\
ST2 (Selatan) & 50.12 & Sedang & 52.12 & Baik \\
ST3 (Barat) & 51.37 & Baik & 50.47 & Sedang \\
ST4 (Utara) & 46.55 & Sedang & 51.62 & Baik \\
\hline
\end{tabular}

Sumber: Hasil olahan data perimer

Pada Tabel 2 diketahui bahwa kondisi terumbu karang pada Pulau Putri secara umum di semua stasiun telah mengalami kerusakan, berada pada kategori sedang dan buruk. Persentase karang hidup di perairan dangkal sebesar $40.02 \%$, dari luasan hamparan karang sebesar $18308 \mathrm{~m}^{2}$. Tidak berbeda jauh dengan persentase terumbu karang hidup di perairan dalam, berdasarkan analis persen cover coral diketahui mulai mendekati kategori sedang, dengan nilai sebesar 50.32\% dari total luas hamparan karang sebesar $29371 \mathrm{~m}^{2}$. Adanya penuruan persen cover coral reef di stasiun ini, berkaitan erat dengan tingkat pemanfaatan yang tinggi dan telah terjadi dalam kurun waktu yang lama. Kegiatan eksploitasi ikan demersal, ikan hias ekonomis dan terumbu karang hias merupakan faktor penurunan ekosistem terumbu karang di Pulau Putri. Hal ini semakin di perburuk dengan aktivitas wisata snorkeling dalam beberapa tahun trakhir. Kondisi ini terlihat dengan banyaknya karang yang patah (rubble) ditemui di sekitar lokasi tersebut. Menurut laporan World Resources Institute, penyebab kerusakan terumbu karang antara lain adalah pembangunan yang 356 
merubah kawasan tanjung (teluk), pemanfaatan yang berlebih (wisata bahari), cara penangkapan ikan yang merusak, peningkatan sedimentasi dan polusi baik yang berasal dari limbah industri ataupun limbah domestik (Kunzmann 2004).

Pada perairan dangkal di stasiun 2, persentase terumbu karang berada pada kategori sedang dengan nilai sebesar $43.93 \%$ dari luas total hamparan terumbu karang sebesar $9853 \mathrm{~m}^{2}$. Hal yang sama juga terlihat pada perairan yang lebih dalam, nilai persen cover coral reef di lokasi ini nyaris berada pada kategori sedang yaitu sebesar 50.14\% dari luas hamparan terumbu karang sebesar $12280 \mathrm{~m}^{2}$. Kondisi berbeda terlihat pada stasiun 3 dan 4, laju kerusakan terumbu karang di perairan dangkal masuk dalam kategori buruk dengan nilai persen cover coral reef berurutan sebesar $22.37 \%$ dan $18.13 \%$ dari luas total hamparan sebesar $5760 \mathrm{~m}^{2}$ dan 9405 $\mathrm{m}^{2}$. Indikator kerusakan yang terjadi diduga dilakukan oleh aktivitas manusia yang berlangsung dalam kurun waktu yang lama, terlihat dari kondisi turumbu karang yang mati banyak ditumbuhi algae (DCA).

Sejalan dengan kerusakan terumbu karang pada perairan dangkal, kondisi yang sama juga terjadi pada perairan yang lebih dalam di stasiun 3 dan 4. Berdasarkan analisis persen cover coral reef, stasiun 3 masuk dalam ketegori sedang dengan nilai sebesar $27.55 \%$ dari luasan terumbu karang $9405 \mathrm{~m}^{2}$, sedangkan pada stasiun 4, nilai persen cover coral reef sebesar $24.81 \%$ dari luas hamparan terumbu karang $12723 \mathrm{~m}^{2}$ dan masuk dalam kategori buruk.

Berdasarkan data ini, diketahui bahwa adanya kecenderungan penurunan luasan terumbu karang pada perairan dangkal terjadi karena kegiatan wisata snorkeling yang tidak ramah lingkungan, beberapa wisatawan terlihat mengabaikan keberadaan ekosistem terumbu karang dengan sengaja melakukan foto selfie sambil memegang, mematahkan bahkan ada yang mengambil spesies coral tertentu pada habitat aslinya. Selain itu gerakan dan posisi snorkeling yang salah, berenang di atas hamparan terumbu karang dengan jarak yang terlalu dekat, menyebabkan ayunan fin membentur hewan karang (coral branching) sehingga menyebabkan banyak yang mengalami patah.

Terumbu karang pada perairan dangkal di Pulau Macan Kecil, secara umum mengalami kerusakan yang merata di setiap stasiun. Berdasarkan analisis persen cover coral reef, diketahui kondisi terumbu karang di pulau ini masuk dalam tiga kategori yaitu; buruk, sedang dan baik (Kepmen LH 2004; Yulianda et al. 2010). Nilai kategori baik dalam konteks ini, sesungguhnya telah berada pada level terkecil dalam persentase penilaian, sehingga nyaris masuk dalam ketegori sedang (Giyanto et al. 2017). Keberadaan Pulau Macan Kecil yang telah menerapkan konsep eco-resort, belum memberikan kontribusi yang signifikan terhadap keberlanjutan sumber daya alam (sustainable resources) khususnya ekosistem terumbu karang di sekitar kawasan Pulau Macan Kecil. Hal itu terlihat dengan rendahnya persen cover coral reef di empat stasiun pengamatan, kategori terburuk berada pada stasiun 1, dengan nilai sebesar 19.72\% dari luas total hamparan terumbu karang $4436 \mathrm{~m}^{2}$. Kategori sedang berada pada stasiun 2 dan 4, memiliki nilai persen cover coral reef sebesar $45.71 \%$ dan $34.18 \%$ dari luas masing-masing hamparan terumbu karang $8036 \mathrm{~m}^{2}$ dan $6335 \mathrm{~m}^{2}$. Persen cover coral reef yang masuk dalam kategori baik terdapat pada stasiun 3, dengan nilai $50.25 \%$ dari total hamparan terumbu karang seluas $12932 \mathrm{~m}^{2}$. Walaupun masuk dalam ketegori baik, tetapi kondisi terumbu karang banyak mengalami kerusakan (rubble), sehingga nyaris masuk dalam kategori sedang.

Kondisi berbeda terlihat pada ekosistem terumbu karang di perairan yang lebih dalam. Berdasarkan analisis persen cover coral reef, secara umum seluruh stasiun (1,2,3 dan 4) masuk dalam kategori baik dengan nilai persentase berurutan, $50.18 \%, 50.78 \%, 51.08 \%$ dan $51.32 \%$, dari total luas hamparan terumbu karang masing-masing stasiun sebesar $1960 \mathrm{~m}^{2}, 8343 \mathrm{~m}^{2}, 12759 \mathrm{~m}^{2}$ dan $5895 \mathrm{~m}^{2}$. Perbedaan nilai persentase yang terjadi disebabkan adanya tekanan pemanfaatan yang berbeda, dialami oleh masing-masing lokasi pada Pulau Macan Kecil Ekosistem terumbu karang pada kedalaman 1.5 sampai dengan 5 m, merupakan lokasi yang menarik bagi wisatawan untuk memanfaatkan zona ini sebagai spot wisata snorkeling.

Tingginya pilihan wisata snorkeling, dikarenakan jenis wisata ini merupakan wisata yang mudah, tidak membutuhkan keahlian khusus, peralatan yang digunakan relatif simple, sehingga dapat dilakukan oleh semua orang (wisatawan) dalam menikmati keindahan bawah laut dan terumbu karang. Jika dibandingkan 
dengan ekosistem terumbu karang pada kedalaman 6 sampai dengan lebih dari $12 \mathrm{~m}$ yang lebih sesuai untuk wisata diving, maka kecenderungan wisatawan lebih banyak memilih melakukan wisata snorkeling dibanding diving. Hal ini menyebabkan tekanan pemanfaatan di perairan dangkal relatif lebih besar, berbanding lurus dengan tingkat kerusakan terumbu karang di lokasi tersebut. Berdasarkan pengamatan di lapangan terhadap aktivitas wisata snorkeling, diketahui kerusakan terumbu karang didominasi oleh jenis Coral branching, Acropora brancing, fallious dan sebagian jenis tabulate, bentuk kerusakan bervariasi seperti patah, terlepas dari subtrat, dan tergores.

Status Pulau Kayu Angin Genteng dalam TNL Kepulauan Seribu sebagai zona pemanfaatan wisata bahari cenderung berbeda dengan Pulau Putri dan Macan Kecil, dikarenakan hingga saat ini belum memiliki resort. Wisatawan yang berkunjung umumnya berasal dan menginap di pulau lain terdekat dalam gugusan Kepulauan Seribu. Aktivitas yang berlangsung di daratan maupun lautan di sekitar pulau lebih rendah jika di banding Pulau Putri dan Macan Kecil. Hal ini terlihat saat melakukan observasi lapangan, diketahui bahwa durasi waktu yang dihabiskan wisatawan dalam menikmati aktivitas wisata lebih singkat. Umumnya wisatawan menghabiskan waktu 3 sampai dengan 4 jam dalam sehari dengan interval waktu kunjungan yang berbeda setiap wisatawan. Berdasarkan kondisi ini, maka tekanan pemanfaatan sumber daya alam dari wisatawan lebih kecil jika dibanding kedua pulau lain, tetapi karakteristik pulau dengan luas daratan kurang dari $1 \mathrm{~km}^{2}$, menyebabkan pulau ini lebih rentan mengalami kerusakan ekosistem maupun sumber daya alam yang ada di sekitarnya. Salah satu ekosistem yang rentan mengalami kerusakan ialah terumbu karang.

Dari data yang diperoleh, sebagain besar terumbu karang mengalami kerusakan dengan tingkat yang beragam. Persen cover coral reef di perairan dangkal, terbagi dalam dua kategori, stasiun 1 dan 4, memiliki nilai sebesar $37.33 \%$ dan $46.55 \%$ dari luas total hamparan terumbu karang $3721 \mathrm{~m}^{2}$ dan $560 \mathrm{~m}^{2}$, masuk dalam ketegori sedang, sedangkan pada stasiun 2 dan 3, masuk dalam kategori baik dengan nilai persentase $50.12 \%$ dan $51.37 \%$ dari luas hamparan terumbu karang sebesar $5083 \mathrm{~m}^{2}$ dan $3607 \mathrm{~m}^{2}$. Berdasarkan data yang diperoleh, diketahui Ekosistem terumbu karang di perairan yang lebih dalam secara umum pada semua stasiun tergolong dalam kategori baik, walaupun memiliki nilai persen cover coral reef yang tidak terlalu besar yaitu $55.05 \%, 52.12 \%, 50.47 \%$ dan $51.62 \%$, dari luas hamparan terumbu karang masing-masing stasiun sebesar $4083 \mathrm{~m}^{2}, 6130 \mathrm{~m}^{2}, 4390 \mathrm{~m}^{2}$ dan $788 \mathrm{~m}^{2}$. Kondisi terumbu karang di sekitar perairan Pulau Putri, Macan Kecil dan Kayu Angin Genteng sangat berkaitan dengan parameter fisika-kimia oseanografi. Menurut Edrus et al. (2013) perubahan kondisi perairan dapat secara langsung atau tidak langsung berpengaruh terhadap tutupan karang.

Pengamatan yang dilakukan pada ekosistem terumbu karang di kedalaman perairan dangkal dan dalam pada Pulau Putri, Macan Kecil dan Kayu Angin Genteng, diketahui bahwa tutupan karang hidup (hard coral) sebagai organisme utama penyusun ekosistem terumbu karang lebih banyak didominasi oleh jenis Coral massive (CM) dan Coral branching (CB). Tipe terumbu karang patch reef di ketiga pulau, turut mempengaruhi struktur komunitas organisme terumbu karang yang terdapat di sekitarnya.

Berdasarakan hasil analisis jumlah kelimpahan life form, diketahui bentuk life form terumbu karang pada perairan dangkal lebih banyak yaitu 9 jenis dan pada perairan dalam berjumlah 8 jenis. Perbedaan jumah life form pada dua kedalaman yang berbeda, menjadi indikator bahwa struktur organisme karang dalam membentuk komunitas terumbu karang dapat bervariasi sesuai kedalaman perairan yang merupakan faktor pembatas. Selain itu, perbedaan ini dapat pula terjadi akibat adanya perubahan proses alami ekosistem sehingga menyebabkan sebagian organisme terumbu karang mengalami kerusakan dan mati. Proses adaptasi organisme karang akan sangat bergantung dari kondisi parameter fisika-kimia oeseanografi dalam suatu kawasan. Jumlah life form di ketiga pulau pada kedalaman 1.5 sampai dengan $5 \mathrm{~m}$ dan 6 sampai dengan lebih dari 12 m, dapat dilihat pada Gambar 2 dan 3. 


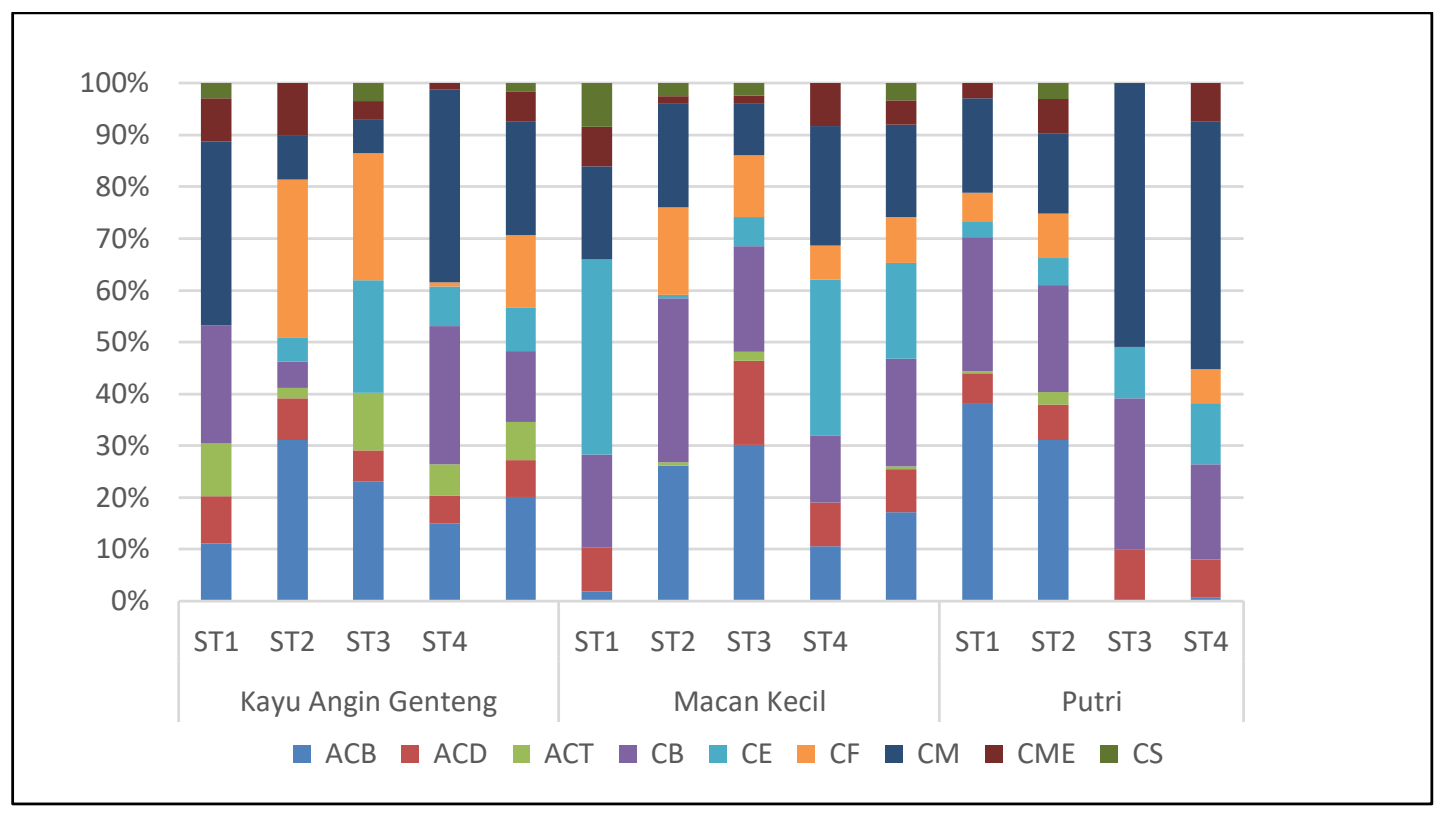

Gambar 2 Jumlah dan persentase life form di kedalaman 1.5 sampai dengan $5 \mathrm{~m}$

Pada Gambar 2 diketahui jumlah persentase life form di perairan dangkal Pulau Putri dan Kayu Angin Genteng pada empat stasiun, didominasi jenis Coral massive (CM) sebesar $132.36 \%$ dan $87.96 \%$, persentase terendah dari jenis coral submassive (CS) $6.33 \%$ dan $2.41 \%$, sedangkan life form pada Pulau Macan Kecil lebih didominasi jenis Coral branching (CB) sebesar 83.00\%, pada Pulau Macan Kecil dan Kayu Angin Genteng, jenis life form terendah dari jenis Acropora tabulate (ACT). Menurut Faizal et al. (2012) karang bercabang (Coral branching) dan Acropora branching sangat umum dijumpai dan bentuk pertumbuhan tersebut merupakan penyusun utama terumbu karang Kepulauan Seribu yang didukung oleh bentuk foliose (lembaran) dan massive.

Tingginya persentase jenis CM pada Pulau Putri, diduga karakteristik pertumbuhan spesies coral ini terjadi secara horizontal flate pada subtrat karang, sehingga mareduksi kontak langsung saat aktivitas wisata snorkeling dilakukan, selain itu bentuknya yang flate di dasar menempel pada subsrat menjadikan jenis terumbu ini lebih resistant terhadap sentuhan atau gesekan dengan objek lain. Kemungkinan kerusakan yang dapat ditimbulkan pada life form ini ialah adanya goresan pada permukaan terumbu.

Berdasarkan data yang diperoleh, jenis Coral branching (CB) dan Acroprora brancing (ACB) memiliki persentase lebih sedikit di zona yang susungguhnya merupakan habitat ideal jenis ini dapat bertumbuh dengan baik. Hal ini disebabkan karena karakteristik (CB) dan (ACB) lebih rentan mengalami kerusakan akibat aktivitas snorkeling. Bentuknya seperti jari dengan pertumbuhan vertikal ke atas menyebabkan jenis ini mudah patah jika bersentuhan dengan objek lain. Aktivitas wisatawan yang tidak bertanggung jawab cenderung mengabaikan keberadaan sumber daya alam saat menikmati kegiatan wisata, menjadi kontributor kerusakan terumbu karang.

Pada Gambar 3 diketahui jumlah persentase life form pada perairan yang lebih dalam di Pulau Kayu Angin Genteng pada empat stasiun didominasi oleh jenis Coral faliose (CF) sebesar 107.99\%, dan terendah Coral mushroom (CMR) sebesar 9.72\%. Pulau Macan Kecil dan Putri, memiliki persentase life form dominan dari jenis Coral branching (CB) sebesar $85.78 \%$ dan $147.03 \%$, tersebar di seluruh stasiun dan terendah dari jenis Coral mellepora (CME) sebesar 12.89\% dan 9.04\%, terdapat hanya pada stasiun 1 dan 2 . Berdasarkan analisis jumlah life form, sebaran jenis yang diperoleh berada dalam relung ekosistem yang luas, dapat ditemui pada setiap stasiun di ketiga pulau yang dianalisis. Walaupun secara kuantitas jumlah spesies yang ada relatif sedikit jika dibandingkan pada perairan dangkal. 


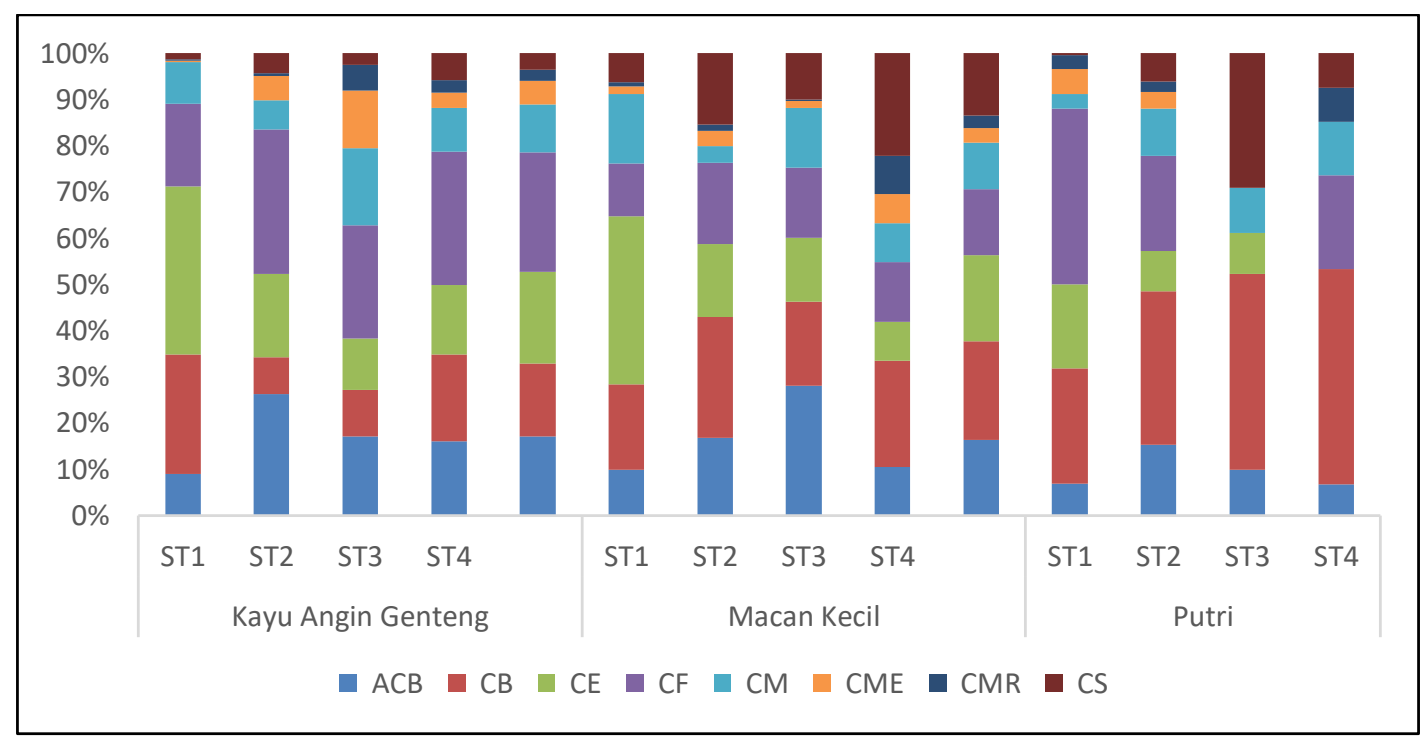

Gambar 3 Jumlah dan persentase life form di kedalaman 6 sampai dengan lebih dari 12 meter

Tingginya persentase life form dan keberadaannya yang luas di setiap stasiun, memberikan penjelasan bahwa ekosistem terumbu karang di perairan laut dalam masih lebih baik dari terumbu karang pada perairan dangkal. Walaupun secara umumnya telah mengalami kerusakan, hingga mempengaruhi persen cover coral reef. Keberadaan life form jenis (CB) di ketiga pulau pada setiap stasiun cenderung tinggi. Hal ini disebabkan karena aktivitas wisata bahari yang dilakukan pada kedalaman ini ialah wisata diving. Jumlah wisatawan yang melakukan diving relatif terbatas dan tidak simultan setiap hari, sehingga tekanan dari aktivitas wisata terhadap sumber daya alam pada ekosistem terumbu karang di kedalaman laut dalam tidak terlalu besar.

Aktivitas yang menyebabkan kerusakan terumbu karang di lokasi ini selain akibat penangkapan ikan dengan bahan peledak, potassium sianida dan pengambilan terumbu karang hias untuk di komersilkan juga terjadi karena aktivitas keluar masuk kapal/perahu motor yang mengantar wisatawan. Berdasarkan pengamatan di lapangan, jumlah kunjungan yang meningkat mendorong banyaknya perahu/kapal motor yang mengantar wisatawan di lokasi spot snorkeling dan diving sering melepaskan jangkar kapal ke dasar perairan yang sebagian besar merupakan ekosistem terumbu karang. Hal ini walaupun tidak besar pengaruhnya tetapi jika terjadi dalam jangka waktu lama dan sering pada spot wisata yang berbeda dapat menyebabkan kerusakan yang lebih besar.

Secara keseluruhan dari hasil pengamatan terhadap kondisi terumbu karang di Pulau Putri, Macan Kecil dan Kayu Angin Genteng, pada masing-masing stasiun, diketahui sebagian besar terumbu karang di lokasi ini telah mengalami kerusakan dengan tingkat yang beragam. Kerusakan yang besar terjadi pada perairan dangkal di Pulau Putri juga di Macan Kecil, sedangkan pada Pulau Kayu Angin Genteng kerusakan terumbu karang mulai berada pada tingkat yang mengkhawatirkan. Kondisi terumbu karang yang masih relatif baik terdapat pada perairan yang lebih dalam, namum tingginya pemanfaatan wisata bahari dan kurang adanya pengawasan dapat menyebabkan ancaman kerusakan ini semakin bertambah.

Menurut (Cleary et al. 2006; Meij et al. 2009) secara umum struktur komunitas terumbu karang di Kepualauan Seribu telah banyak mengalami perubahan di berbagai tempat, hal ini terjadi karena tingginya tekanan terhadap ekosisitem di darat maupun di laut seperti adanya pencemaran, perikanan berlebih dan merusak, tumpahan minyak, perubahan fungsi habitat, aktivitas wisata bahari dan naiknya suhu permukaan laut. 


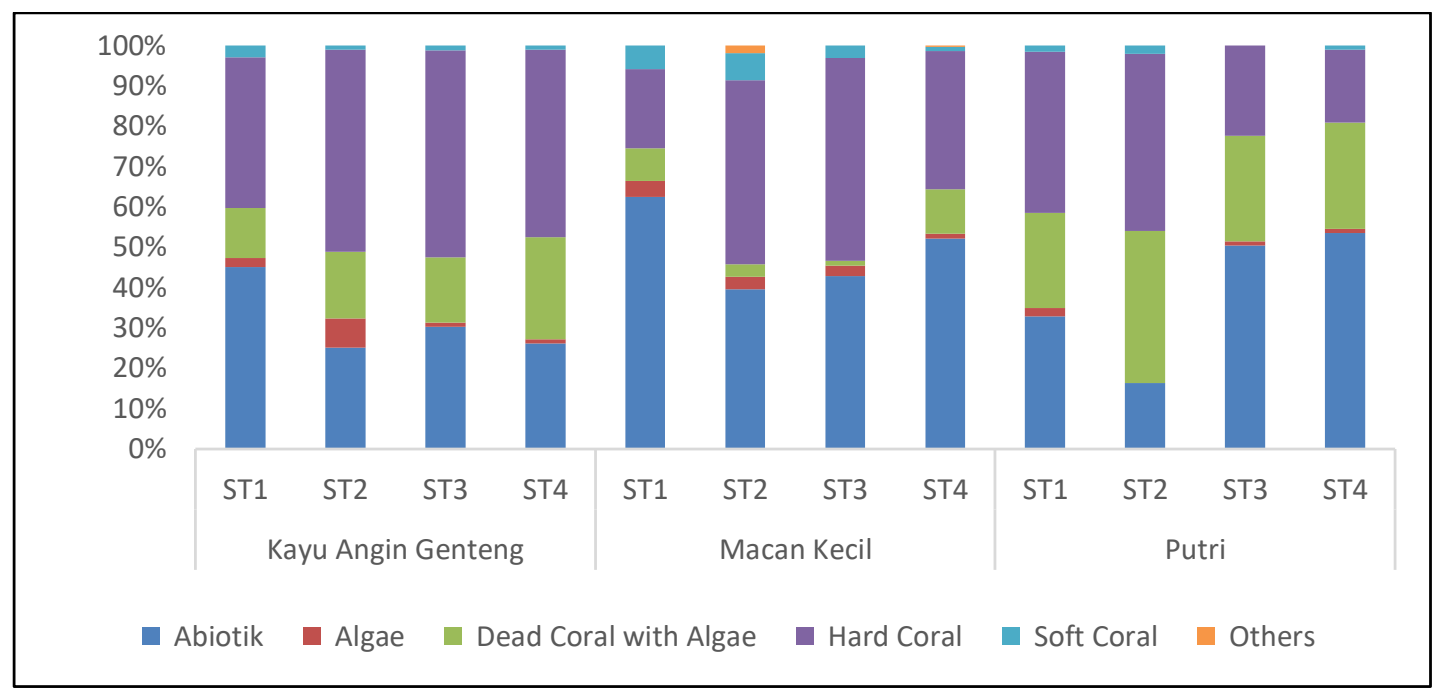

Gambar 4 Kondisi terumbu karang di perairan dangkal

Berdasarkan Gambar 4 diketahui nilai persentase tutupan pada perairan dangkal dan dalam terdiri dari abiotik, algae, dead coral with algae, hard coral, soft coral, others dan sponge menunjukan bahwa lokasi penelitian di tiga pulau memiliki nilai persentase karang keras (hard coral) yang berbeda. Pulau Kayu Angin Genteng masuk dalam kategori baik dan sedang memiliki nilai sebesar 37.33\% sampai dengan 51.37\%, sedangkan pada perairan dalam (Gambar 4), diketahui memiliki persentase antara 50.47\% sampai dengan $55.05 \%$. Pada perairan dangkal di Pulau Macan Kecil dan Putri, persentase hard coral terbagi dalam tiga kategori yakni, buruk, sedang dan baik antara $19.72 \%$ sampai dengan $50.25 \%$, dan antara $18.13 \%$ sampai dengan 43.93\%, sedangkan untuk Pulau Macan Kecil persentase hard coral di perairan yang lebih dalam berada pada kisaran 50.18\% sampai dengan 51.32\% dan Pulau Putri sebesar 27.55\% sampai dengan 50.32\%.

Dari data ini, diketahui bahwa persentase tutupan karang keras terendah berada pada stasiun 1 di Pulau Macan Kecil dan Pulau Putri ada di stasiun 3 dan 4. Karang keras terbagi dalam dua kategori yaitu karang Acropora dan non-Acropora (Englis et al. 1997). Kondisi kesehatan terumbu karang relatif baik umumnya berada pada perairan yang lebih dalam yaitu pada kedalaman 6 sampai dengan lebih dari $12 \mathrm{~m}$, namum kondisi ini berada pada batas yang rentan mengalami penurunan luasan.

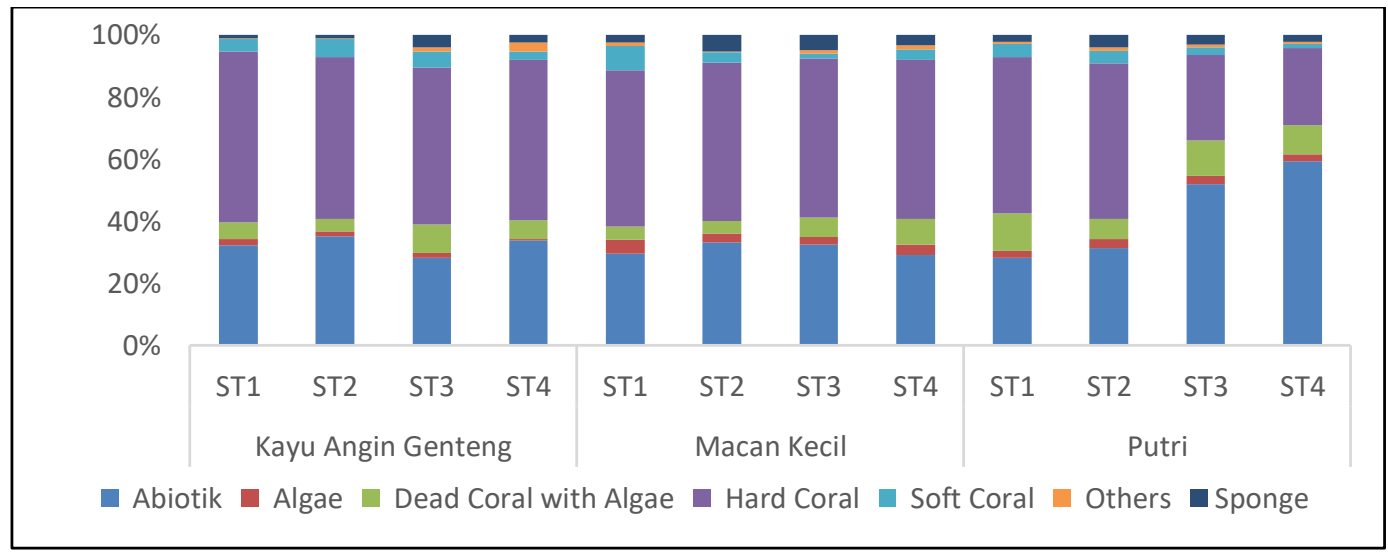

Gambar 5 Kondisi terumbu karang di perairan dalam

Persentase karang mati yang ditemui pada masing-masing stasiun di sekitar ketiga pulau memiliki perbedaan pada setiap stasiun. Jenis karang mati yang ditemui terbagi dalam 2 kategori yaitu karang mati rubble (R) dan dead coral with algae (DCA) (Gambar 5). Dari data yang diperoleh secara umum persentase karang mati ditemukan pada perairan dangkal maupun perairan yang lebih dalam. Pulau Putri mengalami 
kerusakan yang signifikan dan terjadi dalam jangka waktu yang lama. Hal ini terlihat dengan banyaknya karang mati yang telah ditumbuhi oleh alga, dengan perbandingan DCA sebesar 26.15\% sampai dengan $33.62 \%$ dan rubble $13.00 \%$ sampai dengan $48.21 \%$. Kondisi berbeda ditemui pada Pulau Macan Kecil dan Kayu Angin Genteng, berdasarkan data diketahui persentase karang mati lebih didominasi oleh rubble sebesar $34.12 \%$ sampai dengan $58.07 \%$ dan $19.36 \%$ sampai dengan $41.66 \%$, sedangkan persentase karang mati DCA di Pulau Macan Kecil relatif lebih kecil yaitu sebesar 1.14\% sampai dengan $11.10 \%$ dan $12.42 \%$ sampai dengan $25.32 \%$ di Pulau Kayu Angin Genteng. Nilai ini mengindikasikan bahwa kerusakan terumbu karang belum lama terjadi.

Dari jenis kerusakan terumbu karang di Pulau Macan Kecil dan Kayu Angin Genteng lebih didominasi oleh rubble. Diketahui bahwa peningkatan kerusakan yang ada diduga akibat aktivitas wisata bahari yang mengalami peningkatan dalam beberapa tahun terakhir. Hal yang sama juga terjadi pada Pulau Putri, walaupun kerusakan yang ditimbulkan sebagian besar telah terjadi dalam jangka waktu lama tetapi pada bagian barat dan utara peningkatan kerusakan terjadi dalam waktu beberapa tahun terakhir. Hal ini terlihat dengan banyaknya terumbu karang rubble di perairan dangkal maupun perairan dalam, jika dibandingkan dengan DCA relatif lebih sedikit

\section{Kondisi Ikan Karang}

Ikan karang adalah ikan yang hidup dari masa juvenile hingga dewasa di terumbu karang. Menurut Nybakken (1998), ikan karang merupakan organisme yang jumlahnya terbanyak dan juga merupakan organisme besar yang mencolok dapat ditemui di terumbu karang. Ikan karang merupakan sumber daya hayati utama yang hidupnya berasosiasi dan sebagai penghuni terumbu karang. Menurut Omar (2012) sumber protein hewani yang bisa diperoleh dari SDA laut salah satunya ialah jenis ikan karang, manfaatnya yang penting bagi manusia sehingga mendorong beberapa negera di dunia melakukan pembudidayaan dan penangkapan.

Menurut English et al. (1997) mengelompokkan jenis ikan karang ke dalam tiga kelompok utama, yaitu: a) ikan-ikan target, adalah ikan ekonomis penting dan biasa ditangkap untuk konsumsi. Biasanya kelompok ikan-ikan target menjadikan terumbu karang sebagai tempat pemijahan dan sarang/daerah asuhan; b) ikanikan indikator, merupakan jenis ikan karang yang khas mendiami daerah terumbu karang dan menjadi indikator kesuburan ekosistem daerah tersebut; c) ikan-ikan major, adalah jenis ikan berukuran kecil, umumnya 5 sampai $25 \mathrm{~cm}$, dengan karakteristik pewarnaan yang beragam sehingga dikenal sebagai ikan hias. Kelompok ikan-ikan major umumnya ditemukan melimpah, baik dalam jumlah individu maupun jenisnya, serta cenderung bersifat teritorial.

Jenis ikan karang yang berasosiasi dengan terumbu karang di perairan Pulau Putri, Macan Kecil dan Kayu Angin Genteng, secara umum terdiri dari 8 famili. Berdasarkan data yang diperoleh terdapat 3 famili ikan karang dari kelompok ikan mayor seperti; Pomacentridae (ikan betok laut), Labridae (ikan sapu-sapu), dan Blenniidae (ikan peniru), 4 famili dari kelompok ikan target seperti Serranidae (ikan kerapu), Nemipteridae (ikan kurisi), Siganidae (ikan baronang), Scaridae (ikan kakak tua) dan 1 famili dari kelompok ikan indikator yaitu Chaetodontidae (ikan kepe-kepe). Berdasarkan pengamatan ikan karang pada masingmasing stasiun di ketiga pulau, diketahui jumlah jenis ikan karang umumnya berjumlah kurang dari 50 jenis pada reef flat (perairan dangkal) dan kurang dari 100 jenis pada reef slope (perairan dalam).

Untuk melihat spesifikasi jenis ikan pada masing-masing stasiun maka dibagi dalam dua kategori yaitu jumlah dan jenis ikan karang yang berada di perairan dangkal dan jenis ikan karang pada perairan yang lebih dalam. Hasil yang diperoleh dalam pengamatan jenis ikan karang pada dua kategori ini dapat dilihat pada (Gambar 6 dan 7). 


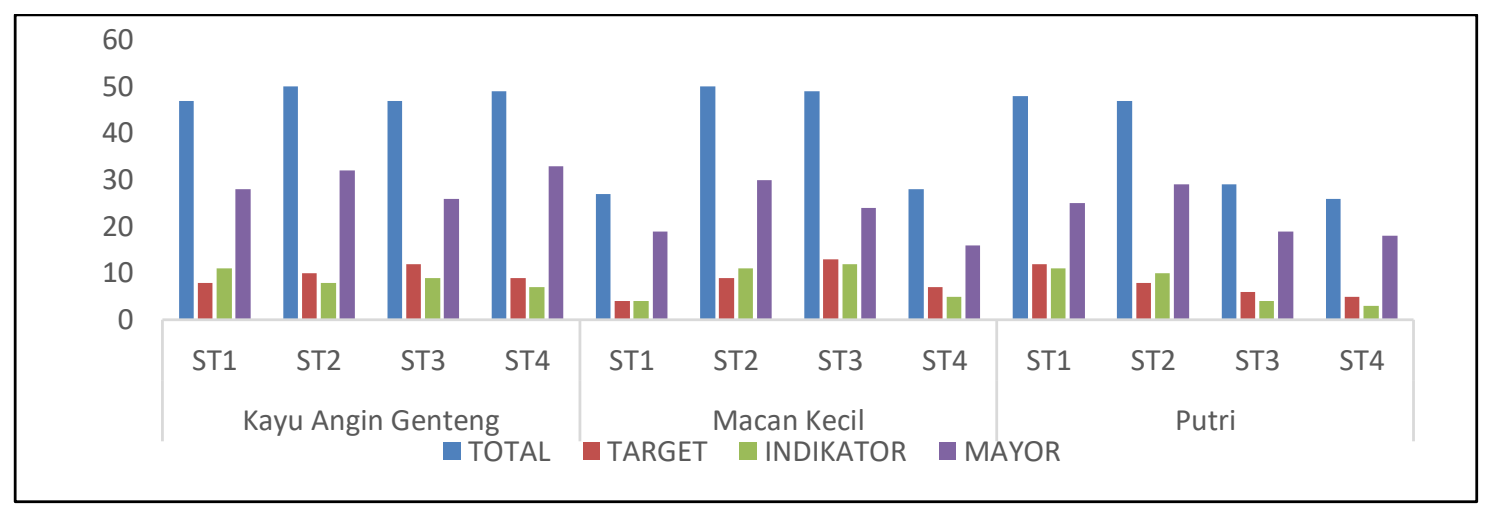

Gambar 6 Keragaman ikan karang pada kedalaman 1.5 sampai dengan 5 meter

Pada Gambar 6 diketahui bahwa sebaran jenis ikan karang untuk kedalaman 1.5 sampai dengan $5 \mathrm{~m}$ adalah berbeda pada masing-masing stasiun. Secara umum jumlah dan jenis ikan karang pada perairan dangkal lebih dari 50 jenis. Berdasarkan analisis kelimpahan ikan karang di Pulau Putri pada kedalaman laut 1.5 sampai dengan $5 \mathrm{~m}$, diketahui total jenis ikan karang paling rendah terlihat pada stasiun 4 yaitu sebanyak 26 jenis, terdiri dari 5 jenis ikan target, 3 jenis ikan indikator dan 18 jenis ikan mayor, sedangkan jumlah terbanyak di Pulau Putri terlihat pada stasiun 1 yaitu sebesar 48 jenis, terdiri dari 12 jenis ikan target, 11 ikan indikator 25 jenis ikan mayor. Rendahnya kelimpahan jenis ikan karang di Pulau Putri terjadi akibat kerusakan terumbu karang yang telah terjadi lama dan terus meningkat pada beberapa tahun terakhir. Kelimpahan ikan karang sangat rendah, khususnya pada bagian barat dan utara yaitu berada di bawah 30 jenis. Tingginya jenis karang mati DCA merupakan salah satu indikator rendahnya pertumbuhan karang baru di sekitar lokasi tersebut. Apabila rekrutmen karang rendah maka pertumbuhan karang baru akan rendah sehingga penambahan penutupan karang akan turut rendah atau tidak berubah (March 2004; Johan et al. 2014).

Pada Pulau Macan Kecil, total kelimpahan ikan terendah ada pada stasiun 1 yaitu sebesar 27 jenis, terdiri dari 4 jenis ikan target, 4 ikan indikator dan 19 ikan mayor, sedangkan jumlah terbanyak ada pada stasiun 2 yaitu sebesar 50 jenis, terdiri dari 9 jenis ikan target, 11 ikan indikator dan 30 jenis ikan mayor. Kelimpahan ikan karang terus menurun dalam beberapa tahun terakhir, seiring peningkatan kerusakan terumbu karang. Rendahnya kelimpahan ikan karang di beberapa stasiun di Pulau Macan Kecil, diduga karena terjadi kerusakan terumbu karang pada kedalaman perairan dangkal semakin besar. Fungsi terumbu karang sebagai habitat sebagian besar jenis ikan karang menjadi berkurang, sehingga banyak spesies ikan karang melakukan migrasi ke ekosistem terumbu karang yang lain. Salah satu indikator kerusakan ekosistem terumbu karang tersebut dapat diidentifikasi oleh semakin menurunnya keanekaragaman jenis-jenis ikan (Badrudin et al. 2003).

Kondisi berbeda terlihat pada Pulau Kayu Angin Genteng, secara keseluruhan dari empat stasiun pengamatan diketahui jumlah kelimpahan ikan karang pada kedalaman 1.5 sampai dengan $5 \mathrm{~m}$ masih berada pada kategori baik. Jumlah terendah terlihat pada stasiun 1 dan 3 dengan nilai total kelimpahan ikan karang sebesar 47 jenis, terdiri dari 8 sampai dengan 12 jenis ikan target, 9 sampai dengan 11 ikan indikator dan 26 sampai dengan 28 ikan mayor, sedangkan kelimpahan tertinggi ada pada stasiun 2 yaitu sebesar 50 jenis, terdiri dari 10 jenis ikan target, 8 ikan indikator dan 32 jenis ikan mayor. Tingginya nilai kelimpahan jenis ikan karang di sekitar perairan Pulau Kayu Angin Genteng disebabkan kondisi ekosistem terumbu karang masih relatif lebih baik, jika dibanding Pulau Putri dan Macan Kecil. Hal ini didukung dengan parameter fisika-oseanografi di sekitar perairan yang berada dalam kondisi baik.

Total jumlah kelimpahan ikan karang pada perairan yang lebih dalam pada setiap stasiun di ketiga pulau secara umum berada dalam kondisi ideal yaitu sebesar $>50$ dan $<100$ jenis ikan karang. Namum pada stasiun 3 dan 4 di Pulau Putri terlihat sangat kecil yaitu sebesar 18 sampai dengan 19 jenis ikan karang (Gambar 7). 


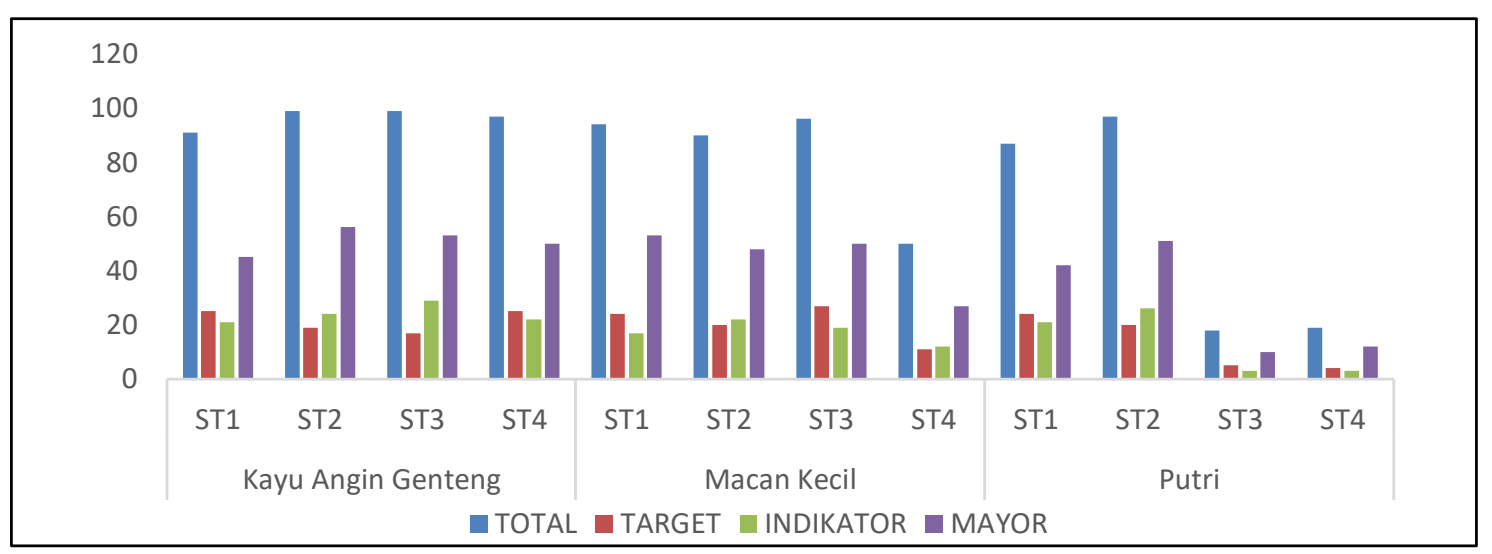

Gambar 7 Keragaman ikan karang pada kedalaman 6 sampai dengan kurang dari 12 meter

Tingginya kelimpahan ikan karang yang terdapat pada beberapa stasiun di ketiga pulau merupakan indikator bahwa terumbu karang pada lokasi tersebut berada dalam kondisi baik. Kehadiran spesies ikan karang pada masing-masing stasiun beragam. Jumlah total jenis ikan karang yang teridentifikasi pada kedalaman 1.5 sampai dengan 5 m di Pulau Putri sebanyak 150 jenis (32\%), total ikan karang Pulau Macan Kecil sebanyak 126 jenis (27\%), sedangkan total ikan karang di Pulau Kayu Angin Genteng sebanyak 193 (41\%). Hasil identifikasi jumlah ikan karang di kedalaman 6 sampai dengan lebih dari $12 \mathrm{~m}$ diperoleh 221 jenis (24\%) ditemukan pada Pulau Putri, 330 jenis (35\%) di Pulau Macan Kecil dan 386 jenis (41\%) berada di Pulau Kayu Angin Genteng (Gambar 6 dan 7). Keberagaman spesies ikan karang yang ditemukan di setiap lokasi pengamatan, disebabkan karena adanya interaksi ikan karang dengan terumbu karang memiliki hubungan langsung sebagai tempat untuk mencari makan, memijah, dan tempat asuhan untuk berlindung dari predator. Menurut Nybakken (1998) mengatakan bahwa tingginya keragaman spesies ikan di terumbu karang dapat disebabkan karena variasi habitat yang terdapat di suatu ekosistem.

Habitat dan kondisi kelayakan ekosistem terumbu karang merupakan indikator adanya perbedaan jumlah dan jenis ikan karang. Secara umum kelimpahan ikan karang dalam suatu ekosistem akan berbanding lurus dengan kualitas perairan di suatu kawasan. Jenis ikan yang menjadi indikasi kelayakan terumbu karang di suatu perairan adalah jenis ikan indikator. Berdasarkan pengamatan untuk jenis ikan indikator di setiap stasiun pada perairan Pulau Putri, Macan Kecil dan Kayu Angin Genteng berasal dari famili Chaetodontidae (ikan kepe-kepe). Untuk jenis ikan target berasal dari beberapa famili seperti; famili Serranidae (ikan kerapu), Nemipteridae (ikan kurisi), Siganidae (ikan baronang) dan Scaridae (ikan kakak tua). Ikan mayor secara umum lebih banyak jumlahnya dari jenis ikan karang yang lain, dari hasil pengamatan diperoleh jenis ikan mayor dari famili Pomacentridae (ikan betok laut), Labridae (ikan sapu-sapu), dan Blenniidae (ikan peniru). Menurut Luthfi et al. (2016) jenis ikan dari famili scaridae bersifat herbivora, memiliki peran yang penting di ekosistem terumbu karang, karena keberadaan ikan ini akan mengontrol pertumbuhan alga di terumbu karang.

\section{SIMPULAN}

Berdasarkan hasil dan pembahasan dari penelitian ini dapat disimpulkan bahwa kondisi ekosistem terumbu karang secara umun pada 3 pulau (Pulau Putri, Pulau Macan dan Pulau Kayu Angin Genteng) di TNKS masih cukup baik, namun pada beberapa spot snorkling terlihat buruk (5 stasiun) dan sedang (6 stasiun) dan kondisi baik hanya 1 stasiun, spot diving kondisi sedang 4 stasiun, buruk 2 stasiun dan baik 6 stasiun. 


\section{DAFTAR PUSTAKA}

Anggraini D. 2008. Analisis potensi wisata bahari di Taman Nasional Kepulauan Seribu Provinsi DKI Jakarta dengan pendekatan Recreation Opportunity Spectrum [tesis]. Bogor: Institut Pertanian Bogor.

Badrudin SR, Suharti, Yahmantoro, Suprihanto I. 2003. Indeks keanekaragaman hayati ikan kepe-kepe (Chaetodontidae) di perairan Wakatobi Sulawesi Tenggara. Jurnal Penelitian Perikanan Indonesia. 9(7): 67-73.

Cleary DFR, Suharsono, Hoeksema BW. 2006. Coral diversity across a disturbance gradient in the Kepulauan Seribu reef complex off Jakarta, Indonesia. Biodiversity and Conservation. 15:3653-3674. doi: 10.1007/s10531-004-4692-y.

Dahuri R. 2003. Keanekragaman Hayati Laut: Aset Pembangunan Berkelanjutan Indonesia. Jakarta: PT Gramedia Pustaka Utama.

Dinas Pariwisata dan Kebudayaan kabupaten Kepulauan Seribu. 2016. Laporan Tahunan Dinas Pariwisata dan Kebudayaan Kabupaten Kepulauan Seribu. Kabupaten Kepulauan Seribu.

Edrus IN, Wijaya SW, Setyawan IE. 2013. Struktur komunitas ikan karang di Perairan Pulau Raya Pulau Rusa, Pulau Rondo dan Taman Laut Rinoi dan Rubiah Nanggroe Aceh Darussalam. Jurnal Penelitian Perikan Indonesia. 4:175-186.

English S, Wilkinson C, Baker V. 1997. Survey Manual for Tropical Marine Resources. Townsville. Australia: Australia Institute of Marine Science.

Estradivari. 2007. Rehabilitasi terumbu Indonesia. National Geographic Indonesia. 3(4):122-125.

Giyanto, Abrar M, Hadi TA, Budiyanto A, Hafizt M, Salatalohy A, Iswari MY. 2017. Status Terumbu Karang Indonesia. Jakarta: LIPI Press.

Goh AH, Sasekumar A. 1980. The community structure of the fringing coral reef, cape rachado. Journal Malay. Nat. 3(4):25-37.

Johan O, Kritanto AH, Haryadi J. 2014. Puncak prevalensi penyakit karang jenis sabuk hitam (black band disease) di Kepulauan Seribu Jakarta. J. Ris. Akuakultur. 9(2):307-317.

Kunzmann A. 2004. Corals, fishermen and tourist. Jo.Naga. 27(1\&2):15-19.

Luthfi OM, Pujarahayu P, Fajar K, Wahyudiarto SA, Fakri SR, Sofyan M, Ramadhan F, Ghofur MA, Murian AS, Tovani I, Mahmud, Adi, Abdi DF. 2016. Biodiversitas dan Populasi Ikan Karang di Perairan Selat Sempu Sendang Biru Kabupaten Malang Jawa Timur. Jurnal Kelautan. 9(1):43-49.

March. 2004. Panduan Dasar Untuk Pengenalan Ikan Karang Secara Visual Indonesia. Jakarta: Penerbit Terangi.

Meij SETVD, Moolenbeek RG, Hoeksema BW. 2009. Decline of the Jakarta Bay molluscan fauna linked to human impact. Mar Pol Bull. 5(9):101-107.

Nybakken JW. 1998. Biologi Laut: Suatu Pendekatan Ekologis. Jakarta: PT Gramedia.

Omar SBA. 2012. Dunia Ikan. Yogjakarta: UGM Press.

Souter DW, Linden O. 2000. The health and future of coral reef systems. Ocean \& Coastal Management. 43:657-688.

Yulianda F, Fachrudin A, Hutabarat AA, Hartati S, Kusharjani HSK. 2010. Pengelolaan pesisir dan laut secara terpadu. Jakarta (ID): Korea International Cooperation Agency. 